\title{
STUDI PEMBUATAN MINYAK KELAPA MURNI SECARA ENZIMATIS DENGAN MENGGUNAKAN BERBAGAI TINGKAT KONSENTRASI ENZIM NANAS PADA DUA JENIS KELAPA
}

(Making Virgin Coconut Oil Enzymaticly By Different Concentration of Enzyme on Two Varieties of Coconut)

\author{
Prihanani $^{{ }^{*}}$, Danner Sagala ${ }^{1}$, Yonadi $^{2}$ \\ ${ }^{1}$ Program Studi Agroteknologi Fakultas Pertanian Universitas Prof. Dr. Hazairin, SH \\ ${ }^{2}$ PT. Sandabi Indah Lestari Bengkulu \\ *Korespondensi: prihananihalatu@yahoo.com
}

\begin{abstract}
Virgin coconut oil can be proccessed in many ways to meet market quality. One of them is enzymaticly process. The aim of this research was to know bromelin enzyme concentration on two varieties of coconut. The experiment was conducted at PT. Sandabi Indah Lestari laboratory, Lunjuk Village, Seluma Barat Subistrict and Seluma Regency from in July 2012. The experiment was arranged in completely randomized design with two factos and three replication. The first faktor was variety of coconut consisted of Kelapa dalam and Kelapa hibrida. The second factor was bromelin enzyme concentration consisted of LIPI enzyme (as control), 50, 100, 150 gram. Variety affected most significantly on virgin coconut oil rendement. Kelapa dalam variety produced the higher virgin coconut oil than kelapa hibrida variety. However, variety and enzyme were affected unsignificant on water content of the virgin coconut oil.
\end{abstract}

Key word: virgin coconut oil, enzyme, bromelin, kelapa dalam, kelapa hibrida

\section{PENDAHULUAN}

Kelapa (Cocos nucifera) merupakan salah satu dari sembilan bahan pokok sehingga memiliki peranan yang sangat strategis bagi masyarakat Indonesia. Hal itu terlihat dari total luas perkebunan kelapa di Indonesia yang mencapai 3.712 juta hektar $(31,4 \%)$ dan merupakan luas areal perkebunan kelapa terbesar di dunia, disusul oleh Filiphina 3.314 juta hektar (27\%), India 1.880 juta hektar (15.8\%). Sri Langka 0.442 juta hektar $(3,7 \%)$ dan Thailand 0.377 juta hektar (3.1\%) (Alamsyah, 2005).

Produk kelapa di Indonesia umumnya dipasarkan dalam bentuk primer atau belum diolah lebih lanjut. Proses pengolahan kelapa yang selama ini dipraktikan secara konvensional dapat diperbaiki melalui penggunaan teknologi yang tepat dan penerapan prinsip-prinsip dasar optimasi, sehingga kualitas produk yang dihasilkan akan meningkat. Proses pengolahan ini menyebabkan pemanfaatan hasil samping (daur ulang) yang mengandung potensi ekonomi menjadi lebih tinggi (Alamsyah, 2005).

Buah kelapa bisa diolah menjadi minyak kelapa murni. Kualitas minyak kelapa murni sangat berkaitan dengan kandungan asam laurat, kadar asam lemak bebas (Free fatty acid) dan kadar airnya serta parameter laboratoris lainnya. Ciri-ciri minyak kelapa murni berkualitas adalah kadar air, asam lemak bebas dan kekeruhan yang rendah. Kadar air dan asam lemak bebas minyak kelapa murni maksimum masing-masing 0,5\% dari beratnya (Alamsyah, 2005)

Pengolahan kelapa menjadi VCO yang memenuhi kualitas pasar dapat dilakukan dengan berbagai cara, diantaranya dengan teknologi enzimatis. Enzim yang digunakan akan memecah protein yang berikatan dengan minyak sehingga rendemen VCO lebih tinggi. Enzim akan menghasilkan ekstraksi minyak kelapa murni yang baik dengan kadar air yang rendah. Enzim yang biasa digunakan dalam proses minyak kelapa murni adalah dari buah nanas, daun pepaya, ragi tempe dan ragi tape. Hasil penelitian 
pendahuluan menunjukan bahwa enzim nanas lebih baik dari enzim lainnya dalam menghasilkan VCO yang baik.

Dari uraian diatas, perlu dilakukan penelitian lebih lanjut terhadap tingkat konsentrasi enzim nanas dan dua jenis kelapa untuk mengetahui konsentrasi enzim nanas yang tepat pada pengolahan minyak kelapa murni (VCO) dari 2 jenis kelapa.

\section{BAHAN DAN METODE}

Penelitian ini dilaksanakan di Laboratorium PT. Sandabi Indah Lestari, Desa Lunjuk, Kec. Seluma Barat, Kab. Seluma, Bengkulu pada bulan Juli 2012. Alat yang digunakan dalam penelitian ini adalah panci, alat pembuka kelapa, alat pemarut, ember plastik transparan, toples besar, selang, timbangan, saringan kelapa, bejana, inkubator, corong, gelas ukur, thermometer, kertas saring, pengaduk, dan bahan yang digunakan adalah : Kelapa dalam dan hibrida, enzim dan air.

Penelitian disusun dalam Rancangan Ancak Lengkap yang terdiri dari 2 (dua) faktor dengan 3 kali ulangan. Faktor pertama adalah jenis kelapa yang terdiri dari Kelapa Dalam dan Kelapa Hibrida. Sedangkan untuk faktor ke dua adalah konsentrasi enzim nanas yang terdiri Kontrol, 50 gram, 100 gram, 150 gram.

Data yang diperoleh diuji dengan uji fisher (uji F), apabila hasil uji berpengaruh nyata atau sangat nyata maka dilanjutkan dengan uji Duncan's Multiple Range Test (DMRT) pada taraf uji 5\%.

\section{Tahapan Penelitian}

Bahan baku untuk pembuatan minyak kelapa murni tanpa proses pemanasan berupa bahan baku utama dan bahan baku tambahan. Bahan baku utama yaitu buah kelapa segar yang sudah tua atau berumur $10-12$ bulan sebanyak 384 buah, terdiri dari 144 kelapa dalam dan 240 buah kelapa hibrida. Sementara bahan baku tambahan berupa enzim nanas sebanyak 1.800 gram, yang berperan untuk memecah emulsi santan sehingga lemak atau minyak dapat berpisah.
Peralatan dan sarana pendukung pada pengolahan minyak kelapa murni secara enzimatis hampir sama dengan pengolahan minyak melalui proses pemanasan. Perbedaannya hanyalah terletak pada proses pemanasan. Selain peralatan yang sama digunakan dengan cara sebelumnya, alat lain yang digunakan adalah Inkubator sebuah sarana untuk memfermentasikan krim yang telah dicampur enzim. Inkubator dilengkapi aliran listrik yang bersuhu tetap.

Tahapan pembuatan minyak kelapa murni secara enzimatis dimulai dari :

\section{Pemarutan kelapa}

Kelapa diparut dengan memakai mesin pemarut, yang bermaksud untuk merusak sel-sel daging buah kelapa sehingga emulsi minyak dalam kelapa dapat dikeluarkan.

2. Penimbangan kelapa parut

Sebelum diperas, kelapa parut ditimbang masing-masing $8 \mathrm{~kg}$ untuk tiap satuan percobaan.

3. Pemerasan santan

Kelapa parut kemudian dicampur dengan 8 liter air untuk tiap satuan percobaan.

4. Fermentasi santan

Fermentasi santan dilakukan untuk memisahkan campuran antara krim (bibit minyak), skim (kaya protein) dan endapan. Bagian yang dimanpaatkan untuk membuat minyak kelapa murni adalah krim. Fermentasi santan dilakukan selama 1 jam, dimulai pada saat santan pertama kali difermentasikan dan dicatat waktunya.

5. Pengambilan krim

Karena hanya krim yang akan digunakan dalam penelitian ini, krim diambil dengan cara menyedot lapisan skim dan air dengan menggunakan selang plastik kecil, kemudian diletakan ke dalam wadah.

6. Pengukuran krim

Setelah didapat krim, kemudian di ukur dengan menggunakan gelas ukur dan dicatat untuk masing-masing satuan percobaan. Jumlah krim yang didapat akan menentukan rendemen dan jumlah minyak yang dihasilkan.

7. Pencampuran enzim 
Enzim merupakan katalis dalam proses pembuatan minyak kelapa murni. Enzim yang digunakan berasal dari enzim nanas. Fungsi enzim adalah sebagai katalis dalam memecah emulsi santan sehingga minyak dapat terpisahkan dari santan. Untuk tiap satuan percobaan diberikan enzim sesuai dengan perlakuan dan diaduk dengan merata.

8. Proses inkubasi

Setelah dicampur dengan enzim, supaya reaksi kimia dapat berjalan, selanjutnya dimasukkan kedalam inkubator dengan suhu $40-50^{\circ} \mathrm{C}$ dan dibiarkan selama 36 jam. Usahakan inkubator yang dipakai tidak berhubungan dengan udara luar sehingga tidak terjadi kontaminasi dengan mikroba atau mikroorganisme lain yang dapat merusak kualitas minyak kelapa murni yang dihasilkan. Setelah 36 jam maka akan terpisah antara minyak, blondo dan air.

9. Pengambilan minyak

Minyak kelapa kemudian diambil dengan menggunakan selang atau sendok secara manual. Pengambilan minyak diberlakukan sama untuk semua satuan percobaan.

10. Pengukuran minyak yang dihasilkan Minyak yang dihasilkan pada tiap satuan percobaan kemudian dihitung jumlahnya dengan cara mengukurnya dengan menggunakan gelas ukur.

11. Perlakuan penyaringan dan pengamatan dalam Penelitian ini meliputi Rendemen, dan Kadar air.

\section{Parameter Yang Diamati}

Parameter yang diamati dalam penelitian ini meliputi :

1. Rendemen minyak

Rendemen minyak kelapa diukur dengan cara menghitung jumlah minyak kelapa murni yang dihasilkan (mililiter) dari jumlah krim yang digunakan dikalikan $100 \%$.

2. Kadar air

Kadar air dihitung dengan menggunakan metode thermogravimetri. Prosedurnya yaitu botol dan tutup yang telah dikeringkan selama 15 menit dalam eksikator kemudian ditimbang beratnya (A), ditimbang sampel minyak kelapa murni sebanyak 5 gram (B). Botol yang sudah disiapkan di isi dengan minyak sampel dan kemudian dimasukkan ke dalam oven selama 3 - 5 jam, setelah selesai botol beserta isi dipindahkan kedalam eksikator dan setelah kering dilakukan penimbangan kembali. Proses penimbangan dilakukan berulang kali sampai beratnya konstan (C). Kadar air dari bahan dapat ditentukan dengan rumus:

$$
\text { Kadar air }=\frac{\mathrm{A}+(\mathrm{B}-\mathrm{C})}{\mathrm{A}+\mathrm{B}}
$$

\section{HASIL DAN PEMBAHASAN}

Perlakuan jenis kelapa memberi pengaruh nyata terhadap rendemen, namun berpengaruh tidak nyata terhadap kadar air. Hal ini dikarenakan bahwa setiap jenis atau varietas kelapa memiliki komposisi kimia yang berbeda. (Towaha et al, 1999; Hairi, 2010). Perlakuan enzim dan interaksi antara jenis kelapa dan enzim tidak berpengaruh nyata baik terhadap rendemen minyak kelapa maupun kadar air (tabel 1).

Perlakuan kelapa dalam memberikan hasil berbeda nyata dengan kelapa hibrida dimana rendemen minyak kelapa dalam lebih tinggi dibandingkan minyak kelapa hibrida (tabel 2). Hal ini sesuai dengan pendapat Luluk (2011), yang menyatakan bahwa kelapa yang baik untuk digunakan sebagai bahan pembuatan VCO berasal dari varietas kelapa dalam.

Tabel 1. Rekapitulasi Analisis Sidik Ragam

\begin{tabular}{lcc}
\multicolumn{1}{c}{$\begin{array}{c}\text { Sidik } \\
\text { Ragam }\end{array}$} & $\begin{array}{c}\text { Rendemen } \\
\text { Minyak Kelapa }\end{array}$ & $\begin{array}{c}\text { Kadar } \\
\text { Air }\end{array}$ \\
\hline Jenis & $78,730^{* *}$ & $2,09^{\mathrm{ns}}$ \\
Kelapa & $0,2006^{\mathrm{ns}}$ & $0,03^{\mathrm{ns}}$ \\
Enzim & $0,734^{\mathrm{ns}}$ & $0,14^{\mathrm{ns}}$ \\
Interaksi & \\
\hline
\end{tabular}

Keterangan: ns : Berpengaruh tidak nyata

** : Berpengaruh sangat nyata 
Tabel. 2. Uji DMRT Pengaruh Jenis Kelapa Terhadap Rendemen Minyak Kelapa

\begin{tabular}{lc}
\hline \multicolumn{1}{c}{ Perlakuan } & Rendemen \\
\hline Kelapa Dalam & 32,12 a \\
Kelapa Hibrida & $29,55 \mathrm{~b}$ \\
DMRT 5 \% & 1.29 \\
\hline
\end{tabular}

Keterangan: angka-angka yang diikuti dengan huruf berbeda, berbeda nyata pada Uji DRMT pada taraf $5 \%$

Jumlah rendemen kelapa dalam yang lebih tinggi dibandingkan dengan kelapa hibrida dikarenakan kandungan galaktomanan dan fosfolipida kelapa dalam rendah sedangkan kandungan galaktomanan dan fosfolipida pada kelapa hibrida lebih tinggi. Galaktomanan tergolong polisakarida yang hampir seluruhnya larut dalam air membentuk larutan kental dan dapat membentuk gel (Barlina et al, 2005). Djadmiko dalam Tenda (2004), menyatakan kandungan galaktomanan yang tinggi menyebabkan sifat kenyal (rubberry) pada kopra sehingga tidak efisien dalam pengolahan minyak. Selain itu Balasubramaniam dalam Barlina et al
(2005), menyatakan bahwa galaktomanan, fosfolipida dan protein dapat berfungsi sebagai emulsifier (pemantap emulsi) pada santan. Sehingga apabila kelapa yang memiliki kandungan galaktomanan dan fosfolipida tinggi proses pemecahan emulsi dalam pembentukan minyak lebih sulit.

Pemberian beberapa tingkat konsentrasi bromelin yang tidak memberikan pengaruh nyata pada rendemen VCO maupun kadar air berbeda dengan hasil penelitian Hairi (2010) dan Luluk (2011) yang menyatakan pemberian bromelin pada konsentrasi yang berbeda memberikan hasil yang sangat berpengaruh nyata.

Perbedaan hasil ini diduga karena pada penelitian ini setiap satuan percobaan didasarkan pada jumlah kelapa parut $8 \mathrm{~kg}$ yang dicampur air 8 liter bukan pada volume krim santan. Hal ini menyebabkan volume krim santan yang digunakan pada setiap satuan percobaan berbeda-beda dengan kisaran 5-6 liter. Perbedaan volume krim santan untuk setiap satuan percobaan ini menyebabkan kondisi yang seharusnya diharapkan tidak tercapai.

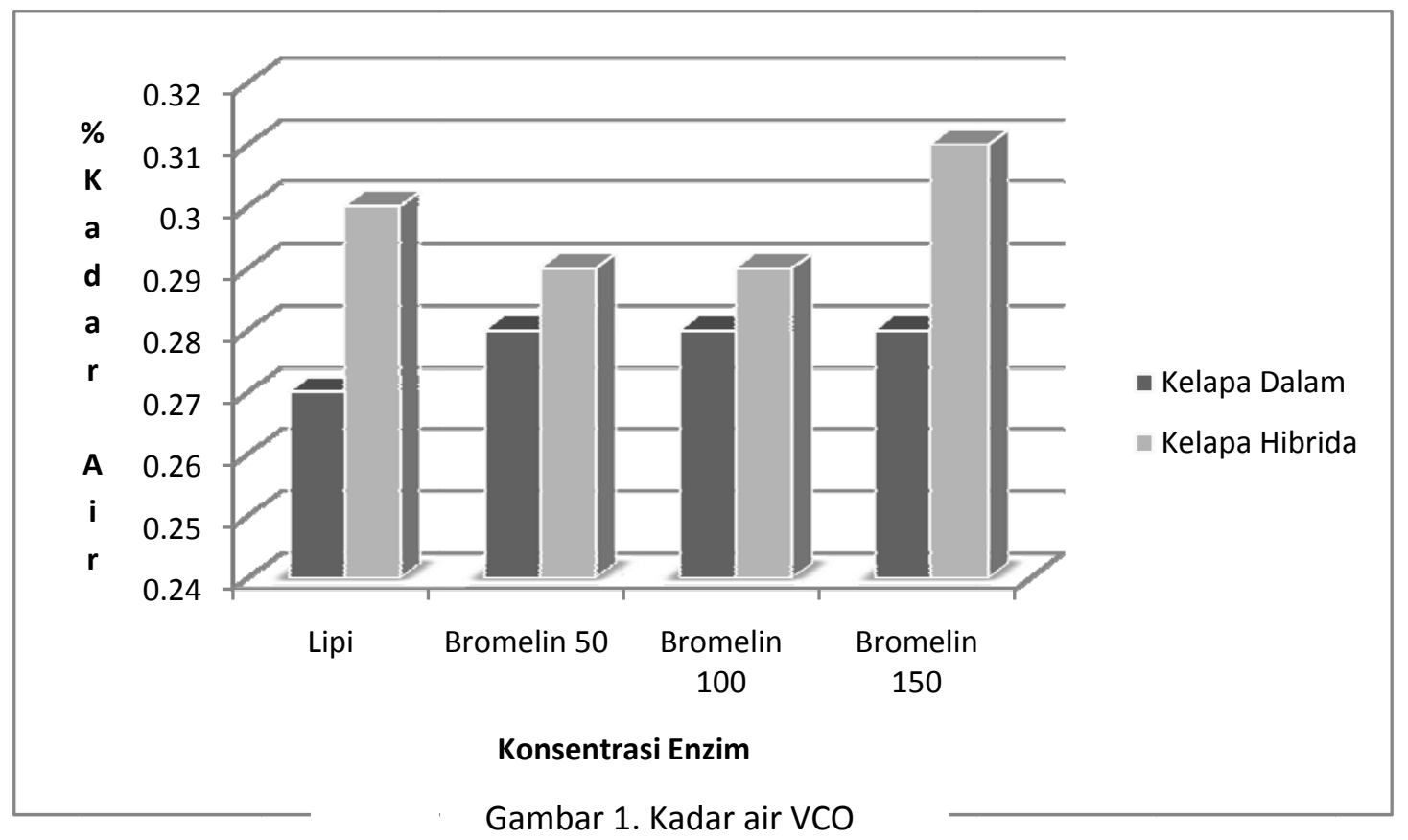




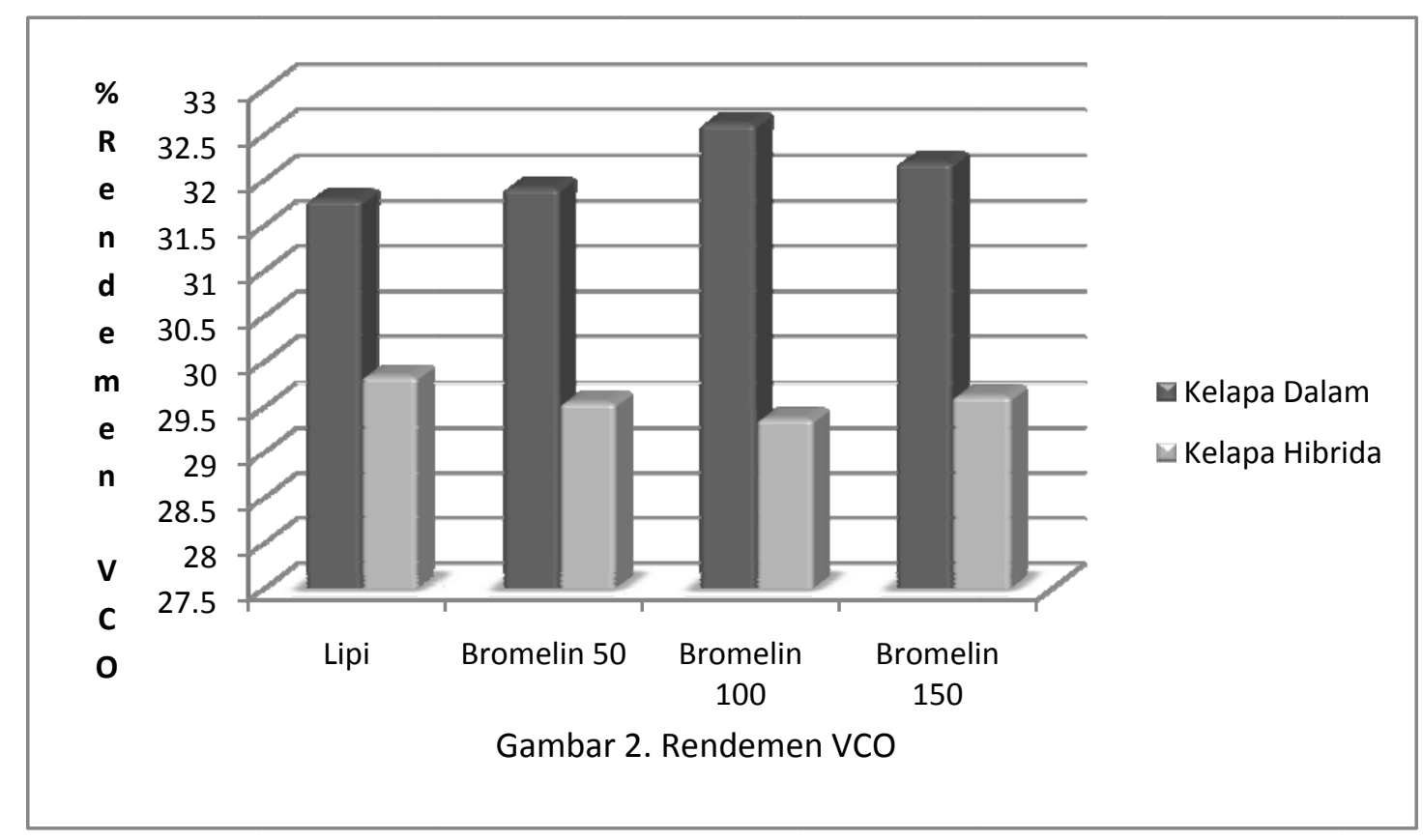

Umur nenas yang digunakan sebagai bahan ekstrak kasar bromelin juga diduga mempengaruhi hasil yang didapatkan. Pada penelitian ini umur nenas yang digunakan relatif tidak sama sehingga diduga mempengaruhi hasil yang didapatkan, karena berdasarkan hasil penelitian Hairi (2010), umur buah nenas berpengaruh terhadap rendemen VCO yang dihasilkan. Hal ini dikarenakan keaktifan enzim bromelin pada nenas muda lebih tinggi dibanding buah nenas lebih tua.

\section{KESIMPULAN}

Dari hasil penelitian yang dilakukan dapat disimpulkan hal sebagai berikut :

1. Varietas kelapa dalam memberikan rendemen VCO yang lebih tinggi dibandingkan varietas kelapa hibrida

2. Kadar air VCO yang dihasilkan dengan metode enzimatis dengan menggunakan ekstrak nenas (bromelin) sebesar 0,270,31 \% berada pada rentang standar yang ditetapkan oleh AFCC yaitu 0,1 $0,5 \%$

\section{DAFTAR PUSTAKA}

Alamsyah AN. 2005. Mengenal Lebih Dekat Virgin Coconut Oil. Minyak Penakluk Aneka Penyakit. Argomedia Pustaka Depok.
Barlina, et al, 2005. Karakteristik Daging Buah Kelapa dan Kesesuaiannya dengan Produk. Balai Penelitian Tanaman Kelapa Dan Palma Lain. http://www.scribd.com/document_down loads/direct/68451233

Djatmiko, B dan Irawadi. 1981. Pengolahan Kelapa 1. Fakultas Teknnologi Hasil Pertanian. Institut Pertanian Bogor. Bogor.

Hairi M. 2010. Pengaruh Umur Buah Nanas Dan Konsentrasi Ekstrak Kasar Enzim Bromelin Pada Pembuatan Virgin Coconut Oil Dari Buah Kelapa Typical (Cocos Nucifera L.) Skripsi. Jurusan Kimia. Fakultas Sains Dan Teknologi Universitas Islam Negeri Maulana Malik Ibrahim Malang.

Luluk Endahwati. 2011 Aplikasi Penggunaan enzym Papain Dan Bromelin terhadap Perolehan VCO. UPN Press.

Tenda ET. 2004. Perakitan Kelapa Hibrida Intervarietas dan Pengembangannya di Indonesia. Balai Penelitian Tanaman Kelapa Dan Palma Lain. http://perkebunan.litbang.deptan.go.id/u pload.files/File/publikasi/perspektif/Per spektif_vol_3_No_2_1_Elsye.pdf. 